\title{
Expression of Activity-Dependent Neuroprotective Protein in the Immune System: Possible Functions and Relevance to Multiple Sclerosis
}

\author{
Manjit Braitch ${ }^{a}$ Kiyokazu Kawabe ${ }^{a}$ Mukanthu Nyirenda ${ }^{a} \quad$ Lucie Jean Gilles $^{a}$ \\ R. Adrian Robins ${ }^{b}$ Bruno Gran ${ }^{a}$ Sean Murphy ${ }^{c}$ Louise Showe $^{d}$
}

Cris S. Constantinescu ${ }^{a}$

${ }^{a}$ Division of Clinical Neurology, School of Clinical Sciences, ${ }^{b}$ Division of Immunology, School of Molecular Medical Sciences, Medical School, Queens Medical Centre, Nottingham University, Nottingham, UK; 'Department of Neurological Surgery, University of Washington, Seattle, Wash., and ${ }^{\mathrm{d}}$ Systems Biology Division, Genomics Core, The Wistar Institute, Philadelphia, Pa., USA

\section{Key Words}

Multiple sclerosis - Activity-dependent neuroprotective protein · NAP · Cytokines

\begin{abstract}
Background: Activity-dependent neuroprotector (ADNP) is a neuroprotective molecule containing an 8-amino acid peptide, NAPVSIPQ (NAP), that is sufficient for its neuroprotective effects. Objective: To assess the expression of ADNP in the human immune system in normal subjects and multiple sclerosis patients. Materials and Methods: ADNP expression was assessed in peripheral blood mononuclear cells (PBMCs) from healthy donors and multiple sclerosis (MS) patients using staining with anti-ADNP (NAP) antibodies and markers for T cells, $B$ cells, monocytes and natural killer cells. ADNP mRNA was determined in peripheral blood from MS patients $(n=24)$ and matched controls $(n=21)$. Expression of activation markers CD69 and CD154 and of IFN- $\gamma$ was assessed by flow cytometry in stimulated PBMCs. Effects of NAP on immune cell proliferation was assessed by
\end{abstract}

tritiated thymidine incorporation. Results: Monocytes, B cells and T cells, but not regulatory (CD4+CD25+) T cells expressed ADNP. NAP peptide decreased the expression of CD69, CD154 and IFN- $\gamma$ in PBMC and caused suppressed anti-CD3-/anti-CD28-stimulated PBMC proliferation. ADNP mRNA was reduced in MS compared to control peripheral blood. Conclusion: ADNP is expressed in many immune system cells. ADNP mRNA is reduced in PBMCs in MS. The peptide NAP, which plays an important role in neuroprotection, has potential immunomodulatory properties.

Copyright $\odot 2009$ S. Karger AG, Basel

\section{Introduction}

Activity-dependent neuroprotector (ADNP) was first detected as a protein induced by vasoactive intestinal polypeptide (VIP) in astrocytes [1]. VIP protects neurons against damage through a variety of mechanisms [2]. Treatment with VIP also reduces the severity of experimental autoimmune encephalomyelitis, the animal mod-

\section{KARGER}

Fax +41613061234 E-Mail karger@karger.ch www.karger.com
(C) 2009 S. Karger AG, Basel $1021-7401 / 10 / 0172-0120 \$ 26.00 / 0$

Accessible online at: www.karger.com/nim
Prof. Cris S. Constantinescu

Division of Clinical Neurology, Medical School, B Floor

Queens Medical Centre, Nottingham University, Nottingham NG7 2UH (UK)

Tel. +44 115875 4597, Fax +441159709738

E-Mail cris.constantinescu@nottingham.ac.uk 
el of multiple sclerosis (MS), by suppressing central nervous system inflammation [3]. Although ADNP mediates neuroprotective effects of VIP, it has also been shown to be neuroprotective in a variety of other experimental models [4]. In humans, ADNP is expressed in the spleen, peripheral blood leukocytes, cerebellum, hippocampus, cerebral cortex [5] and astrocytes [6]. Quintana et al. [7] also showed ADNP expression in macrophages.

Human ADNP contains 9 zinc fingers, a homeobox domain, a nuclear localization signal, a cellular export and import signal [5], and a signal peptide that may indicate a secreted protein [8].

ADNP contains an 8-amino acid sequence, NAPVSIPQ (termed NAP), which provides neuroprotection in vitro and in vivo in a variety of neuronal injury models [9]. This short peptide elicits neuroprotection by interacting with neurons [6], binding to tubulin and stabilizing microtubules [10], and its cellular uptake may not require surface receptors [6]. In addition to the neuroprotective effect, ADNP (NAP) also has immunomodulatory effects. Quintana et al. [7] showed that NAP suppressed production of pro-inflammatory cytokines TNF- $\alpha$, IL- 6 and IL-12 from murine macrophages. We recently observed a reduced expression of ADNP in peripheral blood mononuclear cells (PBMCs) of MS patients as part of our microarray studies of gene expression. This led us, in the studies presented here, to validate these results by quantifying the expression of ADNP mRNA in peripheral blood from patients with MS and healthy volunteers, and to further analyze the expression of ADNP in cells of the immune system, utilizing markers for $\mathrm{T}$ cells (CD4, CD25, CD3), B cells (CD19), natural killer (NK) cells (CD3-CD56+) and the monocyte-macrophage lineage (CD14). We investigated the effect of NAP on T cell activation by measuring surface expression of CD69 and CD154 and its effect on the expression of the pro-inflammatory cytokine, IFN- $\gamma$. As downregulation of ADNP has effects on cell proliferation [5], we also studied the effects of NAP on the proliferation of PBMCs.

\section{Materials and Methods}

Surface and Intracellular Staining of PBMCs

These studies were approved by the Nottingham Research Ethics Committee (patients) and the University of Nottingham Ethics Committee (healthy controls). PBMCs were isolated from healthy volunteers and patients with MS by gradient centrifugation with Histopaque 1077 (Sigma Aldrich, Dorset, UK). One million cells were surface-stained with $5 \mu \mathrm{l}$ antiCD4 (ECD), $5 \mu \mathrm{l}$ CD25 (PC5), $3 \mu \mathrm{l} \mathrm{CD3} \mathrm{(PC7),} 5 \mu \mathrm{l}$ CD19 (PE; all from Beckman Coulter, Fullerton, Calif., USA) and the relevant isotypes. PBMCs were left to stand in the dark on ice for $30 \mathrm{~min}$. Cells were incubated in $500 \mu \mathrm{l}$ of $2 \%$ formaldehyde at room temperature for a further $5 \mathrm{~min}$. Cells were washed in $1 \mathrm{ml} \mathrm{PBA}$ (phosphate-buffered saline, $0.5 \%$ bovine serum, $1 \%$ sodium azide) and resuspended in $1 \mathrm{ml}$ saponin buffer (PBA, $0.1 \%$ Saponin) for permeabilization. Cells were washed twice in saponin buffer containing $10 \%$ FCS. Cells were then stained with $1 \mu \mathrm{g}(5 \mu \mathrm{l})$ of the primary ADNP antibody (Abcam, Cambridge, Mass., USA), incubated for $30 \mathrm{~min}$, and washed in saponin buffer. Cells were then incubated with $5 \mu$ l of the secondary antibody conjugated to FITC (Abcam), washed with saponin buffer, and fixed with $0.5 \%$ formaldehyde. Preliminary blocking experiments showed that incubation of the anti-ADNP (NAP) antibody with excess NAP peptide consistently reduced fluorescence staining by $>80 \%$.

For studies of the effect of NAP on lymphocyte proliferation and IFN- $\gamma$ production, one million PBMCs were stimulated in vitro with $1 \mu \mathrm{g} / \mathrm{ml}$ anti-CD3 and anti-CD28 (Ab Beckman Coulter, Roissy, France) or $20 \mathrm{ng} / \mathrm{ml} \mathrm{PDB}$ and $5 \mu \mathrm{g}$ Ionomycin (Sigma Aldrich) with or without different concentrations of the synthetic peptide NAP $(0,0.25,0.5$ and $1 \mu \mathrm{g} / \mathrm{ml}) ; 10 \mu \mathrm{g} / \mathrm{ml}$ of brefeldin was added $8 \mathrm{~h}$ prior to intracellular staining with anti-IFN- $\gamma$ (Beckman Coulter, Fullerton, Calif., USA). NAP was synthesized in the polymer synthesis laboratory at the University of Nottingham. Cells were incubated for $18 \mathrm{~h}$ at $37^{\circ} \mathrm{C}, 5 \% \mathrm{CO}_{2}$. Intracellular staining for IFN- $\gamma$ conjugated to FITC $(5 \mu \mathrm{l})$ and surface staining with anti-CD69 conjugated to $\mathrm{PE}(5 \mu \mathrm{l})$ and $\mathrm{CD} 154$ conjugated to PC5 $(2 \mu \mathrm{l})$ was performed as described above. Cells were centrifuged and fixed with $0.5 \%$ formaldehyde. Data acquisition was performed on a Beckman Coulter flow cytometer and data was analyzed by using the WinMDI software.

\section{Proliferation Assay}

Ninety-six-well plates were coated with $1 \mu \mathrm{g} / \mathrm{ml}$ of anti-CD3 (Beckman Coulter, Roissy, France) for $90 \mathrm{~min}$ at $37^{\circ} \mathrm{C}$ and $5 \%$ $\mathrm{CO}_{2}$. The plates were washed 3 times with $200 \mu \mathrm{l}$ ice-cold phosphate-buffered saline (Sigma Aldrich). Increasing concentrations of NAP peptide were added to the wells $(0,0.25,0.5$ and $1 \mu \mathrm{g} /$ $\mathrm{ml})$.

Each condition was done in triplicate; $5 \times 10^{5}$ PBMCs were plated out in a volume of $200 \mu \mathrm{l}$ and incubated for $24 \mathrm{~h}$ at $37^{\circ} \mathrm{C}$ and $5 \% \mathrm{CO}_{2}$. The cells were pulsed with $50 \mu \mathrm{l}$ of (methyl-3H) thymidine (Amersham, Little Chalfont, UK) and further incubated for $16 \mathrm{~h}$ at $37^{\circ} \mathrm{C}$ and $5 \% \mathrm{CO}_{2}$. Cells were harvested onto a Packard uniFilter plate using a MicroMate 96 cell harvester. The plate was left to dry for $4 \mathrm{~h}$. Fifty microliters of scintillation fluid (Microscint TM Packard, Groningen, The Netherlands) were added to each well. Incorporation of methyl-3H thymidine was measured in a $\beta$-counter (microplate scintillation counter; Packard, Erskine, UK) and expressed as average counts per minute.

Quantitative Real-Time Polymerase Chain Reaction

Peripheral blood was obtained from healthy volunteers as well as age- and gender-matched patients with MS. Blood samples were left at room temperature for $3 \mathrm{~h}$ in Paxgene blood RNA tubes (PreAnalytix, Crawley, UK) before processing for total RNA extraction following the manufacturer's instructions. Extracted RNA from each sample was quantified (40-175 ng/ $\mu \mathrm{l})$ and quality evaluated using a spectrophotometer (ND-1000 v3.3.0; Nanodrop, Wilmington, Del., USA). RNA was converted to cDNA. 
The cDNA was diluted and $5 \mu \mathrm{l}$ was used for real-time polymerase chain reaction (PCR). FullVerocity SYBR Green QPCR Master Mix (Stratagene, La Jolla, Calif., USA) was used to measure ADNP expression by real-time PCR. Primer pairs were synthesized by MWG Operon (Eurofin, Ebersberg, Germany). Quantitative PCR was performed with the ADNP primer set $5^{\prime}$-AGGCCAGGGTTACAGTGTTG-3' (forward) and 5'-CTCTGGATGCCTGTGACTGA-3' (reverse).

ADNP mRNA results were based on normalised ratio to the internal standard beta-2 microglobulin (B2MG) (5'-GTGGCCTTAGCTGTG-3, forward and 5'-TGG ATG AAA CCC AGA CAC ATA G-3', reverse). PCR was performed in triplicate conditions; $10 \mathrm{~min}$ at $95^{\circ} \mathrm{C}$ and 40 cycles of $15 \mathrm{~s}$ at $95^{\circ} \mathrm{C}$ and $1 \mathrm{~min}$ at $60^{\circ} \mathrm{C}$. The dissociation curve method was utilised to assess the specificity of the amplified product. Quantitative PCR was performed on a MX4000 Multiplex qPCR system (Stratagene).

\section{Statistical Analysis}

A repeated measure ANOVA test and paired t test were used to analyze the expression of CD69, CD154 and IFN- $\gamma$ between groups. A Mann-Whitney test was employed to observe statistical differences between the mRNA expression of ADNP in peripheral blood from MS patients and healthy controls.

\section{Results}

\section{Expression of ADNP on Normal PBMC}

Expression of ADNP was determined by flow cytometry in PBMCs from 3 healthy control donors and 3 relapsing remitting MS patients in remission. ADNP expression was predominantly localized to the T cells and the monocyte/macrophage lineage. Naturally occurring CD4+CD25+ regulatory $\mathrm{T}$ cells did not express ADNP. There were no differences in ADNP between the normal and MS PBMC subpopulations above; however, there was statistically significant difference in the expression of ADNP in NK cells, which was higher in controls compared to MS patients $(\mathrm{p}=0.001)$. Table 1 shows the expression of ADNP on various cells of the immune system.

\section{Effects of NAP on T Cell Activation}

As expected, upregulation of the activation marker CD69 was observed on PBMCs from healthy volunteers stimulated with $1 \mu \mathrm{g}$ anti-CD3 and anti-CD28. Upregulation of CD69 was reduced in the presence of increasing concentrations of NAP (table 2). The difference was significant at $1 \mu \mathrm{g} / \mathrm{ml} \mathrm{NAP}(\mathrm{p}=0.02)$ and $0.5 \mu \mathrm{g} / \mathrm{ml} \mathrm{NAP}$ $(\mathrm{p}=0.02)$, but not at $0.25 \mu \mathrm{g} / \mathrm{ml}$, although a trend was seen $(\mathrm{p}=0.07)$. Similarly, NAP reduced the expression of CD154 on PDB/ionomycin stimulated PBMCs from healthy controls, at all concentrations: $1 \mu \mathrm{g} / \mathrm{ml}$ NAP ( $\mathrm{p}=$
Table 1. The expression of ADNP on various cells of the immune system in MS patients and healthy controls

\begin{tabular}{llll}
\hline Cell type & Marker & $\begin{array}{l}\text { Controls } \\
\text { mean \% } \\
\text { ADNP+ } \\
\text { cells }\end{array}$ & $\begin{array}{l}\text { Patients } \\
\text { mean \% } \\
\text { ADNP+ } \\
\text { cells }\end{array}$ \\
\hline T cells & CD3 & $72(6.49)$ & $62(13)$ \\
T cells & CD4 & $43.3(8.51)$ & $46(9.3)$ \\
T cells & CD25 & $5.71(1)$ & $8.6(1.8)$ \\
NK cells & CD3-, CD56+ & $4.58(0.66)$ & $0.12(0.03)^{*}$ \\
B cells & CD19 & $10.9(2.39)$ & $16(3.5)$ \\
Monocytes & CD14 & $79.2(2.05)$ & $68(19)$ \\
\hline
\end{tabular}

Figures in parentheses are $\pm \mathrm{SD} .{ }^{*}$ Statistically significant $(\mathrm{p}=0.001)$; other differences were not statistically significant.

Table 2. The expression of CD69 in healthy controls after treatment with NAP

\begin{tabular}{lll}
\hline Stimuli & $\begin{array}{l}\text { Concentration } \\
\text { of NAP, } \mu \mathrm{g} / \mathrm{ml}\end{array}$ & $\begin{array}{l}\text { Mean \% } \\
\text { CD69+ cells }\end{array}$ \\
\hline 0 & 0 & $62(8.3)$ \\
$1 \mu \mathrm{g} / \mathrm{ml}$ anti-CD3/CD28 & 0 & $79(10)^{*}$ \\
$1 \mu \mathrm{g} / \mathrm{ml}$ anti-CD3/CD28 & 1 & $70(12)^{*}$ \\
$1 \mu \mathrm{g} / \mathrm{ml}$ anti-CD3/CD28 & 0.5 & $71(9.5)^{*}$ \\
$1 \mu \mathrm{g} / \mathrm{ml}$ anti-CD3/CD28 & 0.25 & $71(3.1)$ \\
\hline
\end{tabular}

Figures in parentheses are $\pm \mathrm{SD} .{ }^{*} \mathrm{p}<0.05$

$0.01), 0.5 \mu \mathrm{g} / \mathrm{ml} \mathrm{NAP}(\mathrm{p}=0.003)$ and $0.25 \mu \mathrm{g} / \mathrm{ml} \mathrm{NAP}$ $(\mathrm{p}=0.04$; table 3$)$. Baseline expression of CD69 and CD154 in the absence of stimuli were significantly increased in MS compared to controls. Although the PBMCs of MS patients showed very high expression of CD69 which remained high despite NAP (data not shown), a significant downregulation with NAP was seen in PBMCs isolated from MS patients with the activation marker CD154. There was a statistically significant difference at $1 \mu \mathrm{g} / \mathrm{ml} \mathrm{NAP}(\mathrm{p}=0.01)$ and $0.5 \mu \mathrm{g} / \mathrm{ml}$ NAP $(\mathrm{p}=0.008)$ but not at $0.25 \mu \mathrm{g} / \mathrm{ml}(\mathrm{p}=0.25$; table 3).

\section{Effects of NAP on the Expression of IFN- $\gamma$}

There was a statistically significant reduction in the IFN- $\gamma$ expression of PBMCs treated with $0.25 \mu \mathrm{g} / \mathrm{ml}$ NAP. IFN- $\gamma$ expression declined from 8.3 to $4.8 \%$ ( $\mathrm{p}=$ 
Table 3. The expression of CD154 in MS patients and healthy controls after treatment with NAP

\begin{tabular}{lccc}
\hline Stimuli & $\begin{array}{l}\text { Concentration } \\
\text { of NAP, } \mu \mathrm{g} / \mathrm{ml}\end{array}$ & $\begin{array}{l}\text { Controls } \\
\text { mean \% CD154 }\end{array}$ & $\begin{array}{l}\text { Patients } \\
\text { mean \% CD154 }\end{array}$ \\
\hline 0 & 0 & $4.6(1.8)$ & $31(18)^{*}$ \\
PDB $20 \mathrm{ng} / \mathrm{ml}$, ionomycin $5 \mu \mathrm{g} / \mathrm{ml}$ & 0 & $18(3.6)$ & $79(6.8)$ \\
PDB $20 \mathrm{ng} / \mathrm{ml}$, ionomycin $5 \mu \mathrm{g} / \mathrm{ml}$ & 1 & $12(5.7)$ & $71(5.9)$ \\
PDB 20 ng/ml, ionomycin $5 \mu \mathrm{g} / \mathrm{ml}$ & 0.5 & $9.8(3.9)$ & $60(5.2)$ \\
PDB 20 $\mathrm{ng} / \mathrm{ml}$, ionomycin $5 \mu \mathrm{g} / \mathrm{ml}$ & 0.25 & $7.9(2.3)$ & $69(16)$ \\
\hline
\end{tabular}

Figures in parentheses are \pm SD. ${ }^{*} \mathrm{p}<0.05$.

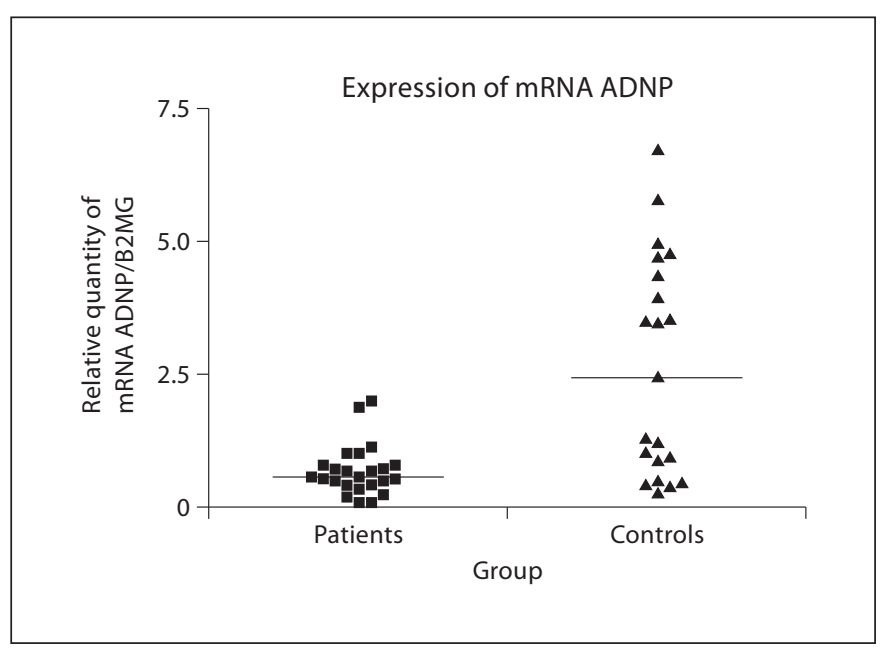

Fig. 1. Expression of ADNP mRNA in peripheral blood of MS patients $(\mathrm{n}=24)$ versus age- and gender-matched control subjects $(\mathrm{n}=21)$. Results represent individual arbitrary units of ADNP mRNA normalised to $\beta-2$ microglobulin mRNA. The horizontal lines represent medians. The expression in controls was significantly higher than in MS patients $(\mathrm{p}<0.001)$.

0.04). There were no statistically significant differences observed with the other peptide concentrations. Similar results were obtained with PBMCs from patients with MS: there was a statistically significant difference in IFN$\gamma$ expression with PBMCs treated with $0.25 \mu \mathrm{g} / \mathrm{ml}$ NAP. IFN- $\gamma$ expression declined from 7 to $5 \%(\mathrm{p}=0.03)$. There was no statistically significant difference observed with the other peptide concentrations.

\section{Proliferation Assay}

The following proliferation results were seen with anti-CD3 treated/anti-CD28-treated PBMC with or without various concentrations of NAP (SD in paren- theses): anti-CD3/anti-CD28 with no NAP, $14,000 \mathrm{cpm}$ $( \pm 4,000)$; anti-CD3/anti-CD28 plus $0.25 \mu \mathrm{g}$ NAP, 9,700 cpm $( \pm 5,400)$; anti-CD3/anti-CD28 plus $0.5 \mu \mathrm{g}$ NAP, $11,000 \mathrm{cpm}( \pm 3,330)$; anti-CD3/anti-CD28 plus $1 \mu \mathrm{g}$ NAP, $11,000 \mathrm{cpm}( \pm 3,800)$. The suppression caused by 1 and $0.5 \mu \mathrm{g}$ of NAP was between 18 and $21 \% ; 0.25 \mu \mathrm{g}$ NAP caused $38 \%$ suppression. There was a statistically significant difference between no NAP versus $1 \mu \mathrm{g}(\mathrm{p}=$ $0.02), 0.5 \mu \mathrm{g}(\mathrm{p}=0.02)$ and $0.25 \mu \mathrm{g}(\mathrm{p}=0.03)$. With PBMC from MS patients, proliferation was reduced by 34,6 and $9 \%$, respectively, for the above doses in decreasing order, but this reduction did not reach statistical significance.

\section{Expression of mRNA ADNP from MS Patients and \\ Control Whole Blood}

To confirm our gene expression studies indicating a reduced expression of ADNP mRNA in MS patients, we collected blood samples from 24 patients with MS, $17 \mathrm{fe}-$ males and 7 males, 1 with secondary progressive, 19 with relapsing remitting MS in remission and 4 relapsing remitting MS patients in relapse and measured ADNP mRNA by quantitative real-time PCR. None of the patients were on disease-modifying treatment. The patients were aged between 30 and 60 years (mean 40 years, SD $\pm 10)$. The healthy volunteer group consisted of $14 \mathrm{fe}-$ males and 7 males aged between 20 and 60 (mean 40 years, SD \pm 10 ).

There was a statistically significant difference in the expression of ADNP mRNA, a lower expression being observed in the MS patients in comparison to the healthy controls ( $\mathrm{p}<0.001$; fig. 1 ).

There were no statistically significant differences between MS clinical subgroups in terms of ADNP mRNA expression. 


\section{Discussion}

We found that monocytes, $\mathrm{B}$ cells, T cells and other immune cells but very few CD4+CD25+ cells (a fraction that mainly includes regulatory $\mathrm{T}$ cells in the absence of activation stimuli) expressed intracellular ADNP. Treatment with the synthetic peptide NAP suppressed the proliferation of anti-CD3-stimulated PBMCs and decreased the activation of $\mathrm{T}$ cells as demonstrated by the reduced upregulation of CD69 and CD154 in response to TCR-mediated activation. CD154 was used as an additional, potentially more responsive marker for $\mathrm{T}$ cell activation because anti CD69 expression was too high, $>90 \%$ in MS patients and not significantly suppressible. There was also a slight decrease in the percentage of cells expressing IFN- $\gamma$ when activated in the presence of NAP. We report, for the first time, a reduced expression of ADNP mRNA in the blood of MS patients compared to controls. These results suggest that ADNP, which has a neuroprotective role in the CNS, also has an immunoregulatory role, which is likely independent of classical natural regulatory $\mathrm{T}$ cells.

This observation is in accord with our microarray results (Showe, L and Constantinescu, CS, unpubl. observations). Our observed ADNP downregulation in MS patients and its protective capacity in experimental autoimmune encephalomyelitis [3] suggests reduced immunoregulatory capacity via ADNP in MS patients. This suggests a role for ADNP/NAP as a potential therapy for MS as the ADNP deficiency may contribute to the defective immunoregulatory mechanisms in people with MS, who also show reduced natural regulatory $\mathrm{T}$ cell function [11].

ADNP has the potential to be a secreted protein [5] implying that its immunoregulatory and neuroprotective peptide NAP may be in the systemic circulation [7], and capable of regulating cells of the immune system, in a cytokine-like fashion, though potentially independent of surface receptors [6]. Inhibition by ADNP/NAP of the activation of autoreactive $\mathrm{T}$ cells may therefore be beneficial in MS [12]. As previously shown [13, 14], both activation markers were expressed at higher level in MS patients compared to controls, even though the patients were in remission. Although, in this small sample, NAP seemed to have a weaker effect on the proliferation of PBMCs from MS patients compared to those from healthy subjects, the effects on activation as assessed by CD154 expression and on IFN- $\gamma$ production were similar. Also, NK cells from MS patients had significantly lower ADNP, and one can speculate that MS patients' NK cells may be less effective in regulating $\mathrm{T}$ cell proliferation [15]. Nevertheless, even if immune cells of MS patients may be less sensitive to immunomodulatory effects of ADNP/NAP, they may be sensitive enough to exhibit reduced inflammatory molecules. Future studies will address potential differences in ADNP responsiveness between immune cells of MS patients and healthy subjects.

It has previously been reported that pro-inflammatory cytokines contribute to peripheral $\mathrm{T}$ cell activation [16]. Our data suggest that NAP caused a downregulation of IFN- $\gamma$. A decrease in the transcription and secretion of IFN- $\gamma$ may partially increase clinical recovery from MS, as previous studies have shown that IFN- $\gamma$ exacerbates MS disease activity [17]. Interestingly, in contrast to the dose-dependent inhibition of CD69 and CD154 expression, IFN- $\gamma$ expression and possibly proliferation were more efficiently inhibited at the lower dose of NAP, suggesting different pharmacological properties for different immune actions.

In conclusion, we have shown that ADNP is expressed in cells of the immune system and that its neuroprotective peptide has immunoregulatory properties. This is an example of neuroimmunomodulation that is relevant to nervous system diseases with both inflammatory and neurodegenerative components, like MS [18]. Our finding of a reduced expression of ADNP in peripheral blood cells of MS patients, that have been found to have reduced regulatory $\mathrm{T}$ cell function, suggest the possibility of an additional deficit of immunoregulation in this inflammatory demyelinating disease.

\section{Acknowledgments}

This study was supported in part by the MS Society of Great Britain and Northern Ireland and by the Stanhope Trust. We thank Anushka Naiken for technical assistance for the proliferation assay.

References

1 Zusev M, Gozes I: Differential regulation of activity-dependent neuroprotective protein in rat astrocytes by VIP and PACAP. Regul Pept 2004;123:33-41.

2 Li H, Mei Y, Wang Y, Xu L: Vasoactive intestinal polypeptide suppressed experimental autoimmune encephalomyelitis by inhibiting $\mathrm{T}$ helper 1 responses. J Clin Immunol 2006;26:430-437.

3 Gonzalez-Rey E, Fernandez-Martin A, Chorny A, Martin J, Pozo D, Ganea D, Delgado M: Therapeutic effect of vasoactive intestinal peptide on experimental autoimmune encephalomyelitis: down-regulation of inflammatory and autoimmune responses. Am J Pathol 2006;168:1179-1188. 
4 Gozes I: Activity-dependent neuroprotective protein: from gene to drug candidate. Pharmacol Ther 2007;114:146-154.

5 Zamostiano R, Pinhasov A, Gelber E, Steingart RA, Seroussi E, Giladi E, Bassan M, Wollman Y, Eyre HJ, Mulley JC, Brenneman DE, Gozes I: Cloning and characterization of the human activity-dependent neuroprotective protein. J Biol Chem 2001;276:708-714.

6 Gozes I, Divinski I: The femtomolar-acting NAP interacts with microtubules: novel aspects of astrocyte protection. J Alzheimers Dis 2004;6:S37-S41.

7 Quintana FJ, Zaltzman R, Fernandez-Montesinos R, Herrera JL, Gozes I, Cohen IR, Pozo D: NAP, a peptide derived from the activity-dependent neuroprotective protein, modulates macrophage function. Ann NY Acad Sci 2006;1070:500-506.

8 Gozes I, Zamostiano R, Pinhasov A, Bassan M, Giladi E, Steingart RA, Brenneman DE: A novel VIP responsive gene. Activity dependent neuroprotective protein. Ann NY Acad Sci 2000;921:115-118.
9 Gozes I, Bassan M, Zamostiano R, Pinhasov A, Davidson A, Giladi E, Perl O, Glazner GW, Brenneman DE: A novel signaling molecule for neuropeptide action: activity-dependent neuroprotective protein. Ann NY Acad Sci 1999;897:125-135.

10 Gozes I, Zaltzman R, Hauser J, Brenneman DE, Shohami E, Hill JM: The expression of activity-dependent neuroprotective protein (ADNP) is regulated by brain damage and treatment of mice with the ADNP derived peptide, NAP, reduces the severity of traumatic head injury. Curr Alzheimer Res 2005; 2:149-153.

11 Viglietta V, Baecher-Allan C, Weiner HL, Hafler DA: Loss of functional suppression by CD4+CFD25+ regulatory T cells in patients with multiple sclerosis. J Exp Med 2004;199: 971-979.

12 Kierdorf K, Wang Y, Neumann H: Immunemediated CNS damage. Results Probl Cell Differ 2009.

13 Kosmaczewska A, Bilinska M, Ciszak L, Noga L, Pawlak E, Szteblich A, Podemski R, Frydecka I: Different patterns of activation markers expression and CD4+ T-cell responses to ex vivo stimulation in patients with clinically quiescent multiple sclerosis (MS). J Neuroimmunol 2007;189:137-146.
14 Balashov KE, Smith DR, Khoury SJ, Hafler DA, Weiner HL: Increased interleukin 12 production in progressive multiple sclerosis: Induction by activated CD4+ T cells via CD40 ligand. Proc Natl Acad Sci USA 1997; 94:599-603.

15 Segal BM: The role of natural killer cells in curbing neuroinflammation. J Neuroimmunol 2007;191:2-7.

16 Martino G, Grohovaz F, Brambilla E, Codazzi F, Consiglio A, Clementi E, Filippi M, Comi G, Grimaldi LM: Proinflammatory cytokines regulate antigen-independent $\mathrm{T}$ cell activation by two separate calcium-signaling pathways in multiple sclerosis patients. Ann Neurol 1998;43:340-349.

17 Panitch HS, Hirsch RL, Schindler J, Johnson KP: Treatment of multiple sclerosis with gamma interferon: exacerbations associated with activation of the immune system. Neurology 1987;37:1097-1102.

18 Frischer JM, Bramow S, Dal-Bianco A, Lucchinetti CF, Rauschka H, Schmidbauer M, Laursen H, Sorensen PS, Lassmann H: The relation between inflammation and neurodegeneration in multiple sclerosis brains. Brain 2009;132:1175-1189. 